\title{
Monitoring water accumulation in a glacier using magnetic resonance imaging
}

\author{
A. Legchenko ${ }^{1}$, C. Vincent ${ }^{2}$, J. M. Baltassat ${ }^{3}$, J. F. Girard ${ }^{3}$, E. Thibert $^{4,7}$, O. Gagliardini ${ }^{2,6}$, M. Descloitres ${ }^{1}$, \\ A. Gilbert ${ }^{2}$, S. Garambois ${ }^{5}$, A. Chevalier ${ }^{1}$, and H. Guyard ${ }^{1}$ \\ ${ }^{1}$ IRD, UJF-Grenoble 1/CNRS/G-INP, LTHE UMR5564, BP 53, Grenoble Cedex 9, 38041, France \\ ${ }^{2}$ Laboratoire de Glaciologie et Géophysique de l'Environnement and CNRS - LGGE, 38041 Grenoble Cedex 9, France \\ ${ }^{3}$ BRGM, BP 6009, 45060, Orléans Cedex 2, France \\ ${ }^{4}$ IRSTEA, UR ETGR, Erosion torrentielle neige et avalanches, 2 rue de la Papeterie-BP 76, \\ 38402 Saint Martin d'Hères, France \\ ${ }^{5}$ Institut des Sciences de la terre (ISTerre), CNRS/ Université Joseph Fourier, Grenoble, France \\ ${ }^{6}$ Institut Universitaire de France, IUF, Paris, France \\ ${ }^{7}$ Université Grenoble Alpes, 38041 Grenoble, France
}

Correspondence to: A. Legchenko (anatoli.legtchenko@ird.fr)

Received: 29 March 2013 - Published in The Cryosphere Discuss.: 31 May 2013

Revised: 14 December 2013 - Accepted: 17 December 2013 - Published: 28 January 2014

\begin{abstract}
Tête Rousse is a small polythermal glacier located in the Mont Blanc area (French Alps) at an altitude of 3100 to $3300 \mathrm{~m}$. In 1892, an outburst flood from this glacier released about $200000 \mathrm{~m}^{3}$ of water mixed with ice, causing much damage. A new accumulation of melt water in the glacier was not excluded. The uncertainty related to such glacier conditions initiated an extensive geophysical study for evaluating the hazard. Using three-dimensional surface nuclear magnetic resonance imaging (3-D-SNMR), we showed that the temperate part of the Tête Rousse glacier contains two separate water-filled caverns (central and upper caverns). In 2009 , the central cavern contained about $55000 \mathrm{~m}^{3}$ of water. Since 2010 , the cavern is drained every year. We monitored the changes caused by this pumping in the water distribution within the glacier body. Twice a year, we carried out magnetic resonance imaging of the entire glacier and estimated the volume of water accumulated in the central cavern. Our results show changes in cavern geometry and recharge rate: in two years, the central cavern lost about $73 \%$ of its initial volume, but $65 \%$ was lost in one year after the first pumping. We also observed that, after being drained, the cavern was recharged at an average rate of 20 to $25 \mathrm{~m}^{3} \mathrm{~d}^{-1}$ during the winter months and 120 to $180 \mathrm{~m}^{3} \mathrm{~d}^{-1}$ in summer. These observations illustrate how ice, water and air may refill englacial volume being emptied by artificial draining. Com-
\end{abstract}

parison of the 3-D-SNMR results with those obtained by drilling and pumping showed a very good correspondence, confirming the high reliability of 3-D-SNMR imaging.

\section{Introduction}

Water circulation in a glacier is an important factor that determines ice dynamics, runoff characteristics, and water quality. The recent, growing, concern over the response of glaciers to future-climate scenarios necessitates understanding of the hydrological processes in ice. A significant proportion of glaciers have a polythermal regime, where ice masses are composed of temperate ice (at the pressure-melting point) and cold ice (Irvine-Fynn et al., 2011). In a polythermal glacier, the coexistence of temperate and cold ice increases the potential for water storage within the glacier's drainage system. Observations at Austre Brøggerbreen in 1998 and 2000 showed that a water volume of approximately $8000 \mathrm{~m}^{3}$ was retained in a single englacial channel (Irvine-Fynn et al., 2011). At Hansbreen, the annual water volumes in englacial conduits were estimated to be about $1.3 \times 10^{6} \mathrm{~m}^{3}$ (Benn et al., 2009). However, the total volume of accumulated water will depend upon channel density and dimensions, glacier size, and the rate at which summer-season outflow 
is curtailed. Water trapped within a glacier can lead to extreme discharge events (Haeberli, 1983; Jansson et al., 2003). In densely populated mountain areas, glaciers may affect a number of hazard-relevant issues, such as abrupt floods (Haeberli et al., 1989) or slope instability (Fischer et al., 2005). A better understanding of the hydrological processes in polythermal glaciers and the design of suitable protection measures against new hazards requires regular observations and detailed knowledge of the internal glacier structure, which can be obtained using surface geophysical methods.

In recent years, ground-penetrating radar (GPR) has been increasingly used for the detection of subglacial and englacial environments (Irvine-Fynn et al., 2006; Bælum and Benn, 2011). Using calibrations and additional temperature data, GPR helped estimate the water content in the ice (Hamran et al., 1996; Macheret and Glazovsky, 2000), and more recent GPR research examined temporal changes in glaciers and investigation of 2-D and 3-D structures (Grasmueck et al., 2004; Gross et al., 2004). Study of ice properties by combining surface and borehole radar measurements improves the accuracy of the results (Murray et al., 2000). Other non-invasive methods, such as seismic techniques (Lanz et al., 1998; Musil et al., 2002; Maurer and Hauck, 2007), frequency- and time-domain electromagnetic methods (FDEM and TDEM, respectively) (Hoekstra, 1978; Hauck et al., 2001) and electrical resistivity tomography (ERT) (Hauck and Vonder Mühll, 2003; Marescot et al., 2003; Kneisel, 2004) provide both redundant and complementary information about glacier features. Joint interpretation of data obtained with different methods provides more reliable and accurate results (Endres et al., 2009; Kim et al., 2010; Merz et al., 2012). However, variations in the physical parameters of the investigated formations observed by these traditional geophysical methods do not allow a unique interpretation in terms of water presence, and hence an estimate of the water volume accumulated in a glacier body can only be qualitative.

In this paper, we report our results of using the surface nuclear magnetic resonance method (SNMR), also known as the magnetic resonance sounding (MRS), for investigating hydrological processes in a glacier. SNMR is an emerging geophysical technique, specifically developed for hydrogeological investigations (Legchenko and Valla, 2002; Hertrich, 2008; Knight et al., 2012). Selective sensitivity to groundwater is the main advantage of SNMR in comparison with other geophysical tools, and the magnetic resonance phenomenon can also be used for investigating brine and water inclusions in ice (Callaghan et al., 1999). Note that cold ice with negligible interstitial water does not produce an SNMR response and will be interpreted as a dry material. However, temperate ice may contain liquid water and SNMR can quantify this water content. In its 2-D and 3-D implementation, SNMR was reported to be an efficient method for investigating subglacial formations (Lehmann-Horn et al., 2011) and for locating water-filled caverns and channels in a karst environ- ment (Vouillamoz et al., 2003; Boucher et al., 2006; Girard et al., 2007; Legchenko et al., 2008). For 2-D and 3-D investigations, SNMR can be used with separate transmitting (Tx) and receiving (Rx) loops (Hertrich et al., 2009), or with a coincident Tx/Rx loop (Legchenko et al., 2011). We have studied the Tête Rousse glacier located in the Mont Blanc area (French Alps) using the latter configuration as being better adapted to high mountain conditions.

\section{The 3-D-SNMR method}

The SNMR field setup consists of a wire loop laid out on the surface, usually in a square with sides between 40 and $150 \mathrm{~m}$. The loop is then energized by a pulse of alternating current $i(t)=I_{0} \cos \left(\omega_{0} t\right)$. The current frequency is set equal to the Larmor frequency of the protons $\omega_{0}$ in the geomagnetic field $B_{0}\left(\omega_{0}=\gamma B_{0}\right.$ with $\gamma$ being the gyromagnetic ratio). The pulse causes precession around the geomagnetic field of the spin magnetization of the protons in groundwater, which creates an alternating magnetic field that can be detected by the same loop after the pulse is terminated (the free-induction decay method). Oscillating at the Larmor frequency, the SNMR signal is measured by varying the pulse moment $q=I_{0} \tau$, with $I_{0}$ and $\tau$ being the amplitude and duration of the pulse, respectively. The distribution of the water content in the subsurface can be derived from inversion of the SNMR signal.

The signal induced in the coincident transmitting/receiving ( $\mathrm{Tx} / \mathrm{Rx}$ ) loop is proportional to the sum of the flux of all precessing magnetic moments and can be computed with the volume integral (Valla and Legchenko, 2002):

$e_{0}(q)=I_{0}^{-1} \omega_{0} \int_{V} B_{1} M_{\perp} w(\boldsymbol{r}) \mathrm{d} V$,

where $M_{\perp}=\sin \left(\gamma B_{1} I_{0}^{-1} q / 2\right)$ is the transverse component of spin magnetization, $\gamma$ is the gyromagnetic ratio, $B_{1}$ is transmitted by the surface-loop magnetic-field component perpendicular to the geomagnetic field, $I_{0}$ is the current amplitude in the loop, $q$ is the pulse moment, $\omega_{0}$ is the Larmor frequency for protons in the geomagnetic field, $0 \leq w(\boldsymbol{r}) \leq 1$ is the water content, and $\boldsymbol{r}=r(x, y, z)$ is the coordinate vector.

The 3-D field setup is composed of overlapped measuring loops covering the area investigated with SNMR. The SNMR signal is independently measured in each receiving loop while varying the pulse moment in the transmitting loop. All individual soundings are incorporated into one data set for the 3-D inversion (Legchenko et al., 2011). For the inversion, the linear Eq. (1) is approximated by a matrix equation

$\mathbf{A w}=\mathbf{e}$, 
where $\mathbf{A}=\left[\tilde{a}_{i, j}\right]$ is a rectangular matrix with the elements representing the amplitude of the magnetic-resonance signal generated by water in corresponding cells. The experimental data set is $\mathbf{e}=\left(\tilde{e}_{1}, \tilde{e}_{2}, \ldots, \tilde{e}_{i}, \tilde{e}_{l}\right)^{T}$, the water content in the corresponding cell is $\mathbf{w}=\left(w_{1}, w_{2}, \ldots, w_{j}, \ldots, w_{J}\right)^{T}$, and the symbol $T$ denotes the transposition. For simplicity, we assume that cell size is constant throughout the investigated volume.

For analyzing the resolution of matrix Eq. (2) we use the singular value decomposition, or SVD (Aster et al., 2005). For that, the matrix $\mathbf{A}$ is presented as

$$
\mathbf{A}=\mathbf{U S V}^{T},
$$

where $\mathbf{U}$ is an $I \times I$ orthogonal matrix representing the data space, $\mathbf{V}$ is an $J \times J$ orthogonal matrix representing the model space, and $\mathbf{S}$ is an $I \times J$ diagonal matrix with nonnegative diagonal elements called singular values. The singular values of $\mathbf{S}$ are arranged in decreasing magnitude. The first $p$ values are nonzero and others may be zero. Very small singular values represent numerical instabilities, which is why we consider only significant singular values and partition $\mathbf{S}$ as

$\mathbf{S}=\left[\begin{array}{ll}\mathbf{S}_{p} & 0 \\ 0 & 0\end{array}\right]$

where $\mathbf{S}_{p}$ is a $p \times p$ diagonal matrix composed of the significant singular values. Thus, we can write a reduced-rank approximation as

$\mathbf{A}=\mathbf{U}_{p} \mathbf{S}_{p} \mathbf{V}_{p}^{T}$

The matrix $\mathbf{U}_{p}$ forms an orthonormal basis for the data space and the matrix $\mathbf{V}_{p}$ for the model space.

The resolution of the inversion can be estimated using the model resolution matrix $\mathbf{R}_{m}$, which is a symmetric matrix describing how the inversion represents the original model and can be computed as

$\mathbf{R}_{m}=\mathbf{V}_{p} \mathbf{V}_{p}^{T}$.

If $\operatorname{rank}(\mathbf{A})=p=J$, then the model will be perfectly recovered by the inversion. If $p=J$, then the resolution will not be perfect.

The uncertainty of the inversion can be estimated assuming independent and identically distributed normal data errors $\sigma^{2}$. For the inversion result $\mathbf{w}$, we define the $95 \%$ confidence intervals as

$\frac{1}{\sigma \sqrt{2 \pi}} \int_{-1.96 \sigma}^{1.96 \sigma} \exp \left(-\frac{w^{2}}{2 \sigma^{2}}\right) \mathrm{d} w \approx 0.95$.

Then we use the covariance for the model

$\operatorname{Cov}\left(\mathbf{w}_{L_{2}}\right)=\sigma^{2} \mathbf{V}_{p} \mathbf{S}_{p}^{-2} \mathbf{V}_{p}^{T}$

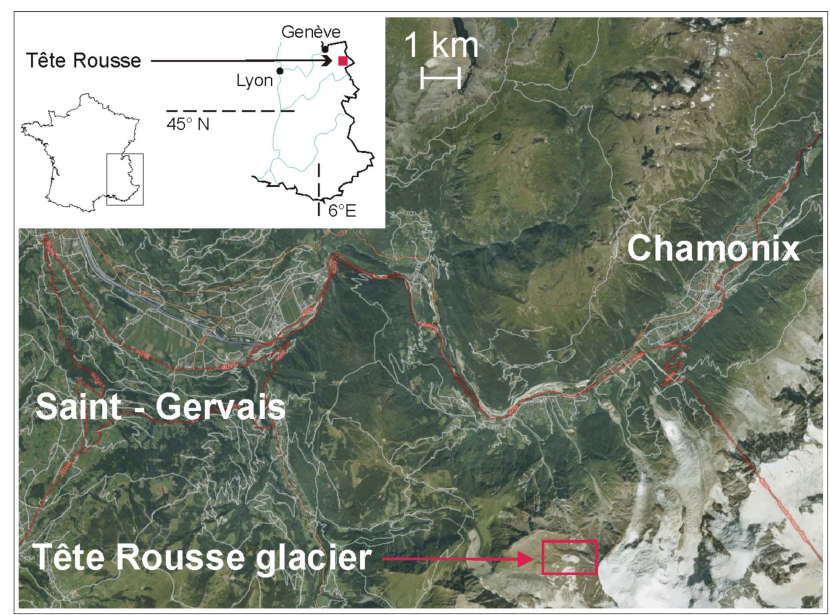

Fig. 1. Location of the Tête Rousse glacier.

The $95 \%$ confidence intervals $\mathbf{w}_{0.95}$ for a model parameter having a normal distribution around the mean $\mathbf{w}_{L_{2}}$ is given as

$\mathbf{w}=\mathbf{w}_{L_{2}} \pm \mathbf{w}_{0.95}$,

where

$\mathbf{w}_{0.95}=1.96 \times \sqrt{\operatorname{diag}\left(\operatorname{Cov}\left(\mathbf{w}_{L_{2}}\right)\right)}$.

Inversion of the 3-D-SNMR data is ill-posed. Different methods for resolving ill-conditioned inverse problems can be found in the literature (e.g., Tarantola, 1987). For our study, the inversion was conducted according to Tikhonov's regularization method (Tikhonov and Arsenin, 1977). To find an approximate solution to the matrix Eq. (2), this method supposes minimization of Tikhonov's functional (Legchenko and Shushakov, 1998):

$T F(\eta)=\|\mathbf{A w}-\mathbf{e}\|_{L_{2}}+S_{x, y, z}=\min$,

where $S_{x, y, z}=\eta_{x} \times\left(\frac{\partial}{\partial x} \mathbf{w}\right)^{2}+\eta_{y} \times\left(\frac{\partial}{\partial y} \mathbf{w}\right)^{2}+\eta_{z} \times\left(\frac{\partial}{\partial z} \mathbf{w}\right)^{2}$ is an estimate of the smoothness of the solution and $\eta_{x}, \eta_{y}, \eta_{z}>0$ are the smoothing factors in each direction. For the optimization itself, we used the conjugate gradient method (Stoer and Bulirsch, 1980).

\section{Investigated area}

The area investigated with 3-D-SNMR is located in the French Alps (Fig. 1). Tête Rousse is a small glacier, whose surface area in 2007 was about $0.08 \mathrm{~km}^{2}$ (Fig. 2). A temperate accumulation area and a predominantly cold ablation area characterize its thermal regime. Reported results of numerical simulations of snow cover and englacial temperatures confirmed by the temperature measurements in boreholes show that the glacier was almost entirely cold before 


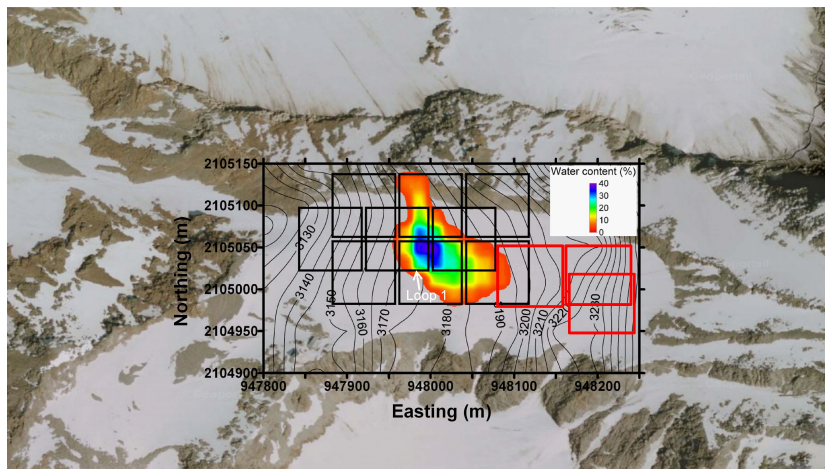

Fig. 2. Aerial photo of the Tête Rousse glacier with an approximate projection of the SNMR measuring loops (black squares) and water-filled cavern detected in 2009 (in the Lambert-II co-ordinate system). Additional SNMR loops used in 2012 are shown as red squares. Isoclines show the elevation of the glacier surface in 2009.

1870, but then gradually warmed up until 1920 (Gilbert et al., 2012). In that year, the glacier was almost entirely temperate except for its central deeper part that remained cold. Between 1920 and 1950, the glacier started freezing again, but the temperate part remained large. Nowadays, except for the first ten meters close to the surface and influenced by seasonal temperature variations, the glacier consists of temperate and cold ice. In its western part, below $3160 \mathrm{~m}$ elevation, the glacier body is composed of cold ice with a temperature below $-2{ }^{\circ} \mathrm{C}$. Above $3180 \mathrm{~m}$, the basal ice is temperate or near temperate in the first 10 to $20 \mathrm{~m}$ above bedrock. In the central part, between 3160 and $3180 \mathrm{~m}$, the ice is temperate from approximately $30 \mathrm{~m}$ below the glacier surface down to bedrock (Vincent et al., 2012a).

Both topology and thermal regime are favorable for water accumulation in the Tête Rousse glacier. In 1892, the outburst flood from this glacier released about $200000 \mathrm{~m}^{3}$ of water mixed with ice and caused much damage (Vallot and Delebecque, 1892; Mougin and Bernard, 1905). Between the catastrophe and 1904, three drainage tunnels were constructed for preventing water accumulation in the glacier. One of the tunnels was maintained until 2009, though no water was drained through this tunnel over the last $106 \mathrm{yr}$. The uncertainty relative to the glacier conditions initiated an extensive glaciological study aiming at evaluating the hazard. In 2007, mapping of the glacier with ground-penetrating radar (GPR) revealed an anomaly that was interpreted as a possible accumulation of water (Vincent at al., 2010). This result initiated a 3-D-SNMR survey in September 2009 that discovered a large water-filled cavern containing about $55000 \mathrm{~m}^{3}$ of water (Vincent et al., 2012b). The 3-D-SNMR data were interpreted alone, though using additional information on the glacier thickness derived from GPR results.

The SNMR results guided a drilling program of more than 20 boreholes, which confirmed the existence of a water-filled cavern and allowed defining the cavern size and location.
Drainage of the cavern revealed a water volume of approximately $48000 \mathrm{~m}^{3}$. This cavern was also investigated with borehole sonar, but its complex shape disturbed the sonar measurements and it was not possible to obtain an entire 3-D model of the cavern. The volume of $24500 \mathrm{~m}^{3}$ obtained from sonar was less than the $55000 \mathrm{~m}^{3}$ estimated with the SNMR method and $48000 \mathrm{~m}^{3}$ confirmed by pumping.

Whatever the mechanism of water penetration into the glacier, this water reached the bottom and was trapped by the thermal barrier formed by cold basal ice. Today, about 3000 people are exposed to the Tête Rousse hazard and the water in the cavity has therefore been pumped every fall since 2010. For monitoring the water accumulation, we used regular 3-D-SNMR surveys. GPR and sonar data were found to be less efficient for monitoring and we did not use these methods for water-volume estimates.

\section{Numerical results}

During our study, we used half-overlapping square loops $\left(80 \times 80 \mathrm{~m}^{2}\right)$ that covered most of the glacier (Fig. 2). Investigation depth with this loop was about $80 \mathrm{~m}$. For investigating the resolution of the inverse problem we discretized the subsurface into equal cells with sizes of $20 \mathrm{~m} \times 20 \mathrm{~m} \times 5 \mathrm{~m}$ and $40 \mathrm{~m} \times 40 \mathrm{~m} \times 10 \mathrm{~m}$. The resolution matrix $\mathbf{R}_{m}$ for these two cell sizes is shown in Fig. 3, which shows that the main diagonal of the resolution matrix clearly dominates in both cases. For the discretization with cells of $20 \mathrm{~m} \times 20 \mathrm{~m} \times 5 \mathrm{~m}$ we obtained $\operatorname{rank}\left(\mathbf{R}_{m}\right) / J=0.86$, and using cells of $40 \mathrm{~m} \times 40 \mathrm{~m} \times 10 \mathrm{~m}$ we obtained $\operatorname{rank}\left(\mathbf{R}_{m}\right) / J=0.9$. Hence, when $\mathbf{R}_{m} \approx \mathbf{I}$ we obtain a good theoretical resolution for both cell sizes. However, assuming a $1 \mathrm{nV}$ noise we can estimate the resolution for a more realistic case. For that, we computed the $95 \%$ confidence intervals using Eq. (10). Figure 4 shows the $95 \%$ confidence intervals for each cell; when using discretization with $20 \mathrm{~m} \times 20 \mathrm{~m} \times 5 \mathrm{~m}$ cells we obtained large $95 \%$ confidence intervals, indicating a poor resolution. Inversion with $40 \mathrm{~m} \times 40 \mathrm{~m} \times 10 \mathrm{~m}$ cells will give a better resolution. Thus we estimated the resolution of 3-D-SNMR inversion to be not better than the $40 \mathrm{~m} \times 40 \mathrm{~m} \times 10 \mathrm{~m}$ target size. Smaller targets cannot be accurately resolved. Note that resolution also depends on the noise level.

When water drains through a glacier, it may accumulate not only in large caverns but also in small volumes that cannot be resolved by 3-D-SNMR inversion. Let us see how the sensitivity of the method is distributed within the area investigated with one SNMR loop. For this, we computed the amplitude of the signal generated by one $20 \mathrm{~m} \times 20 \mathrm{~m} \times 5 \mathrm{~m}$ cell for different cell positions (Fig. 5). Figure 5a shows a horizontal slice corresponding to a depth of $20 \mathrm{~m}$ (top of the cell at $20 \mathrm{~m}$ ) below the loop, which is shown by a black dashed line. The white-line square corresponds to a $40 \mathrm{~m} \times 40 \mathrm{~m} \times 10 \mathrm{~m}$ cell and the numbers 


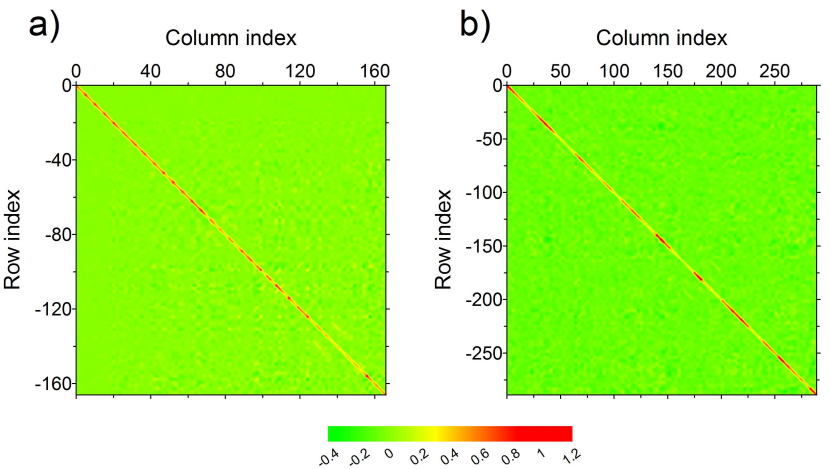

Fig. 3. The model resolution matrix $\mathbf{R}_{m}$ computed considering the discretization of the matrix A: (a) cells of $40 \mathrm{~m} \times 40 \mathrm{~m} \times 10 \mathrm{~m}$; (b) cells of $20 \mathrm{~m} \times 20 \mathrm{~m} \times 5 \mathrm{~m}$.

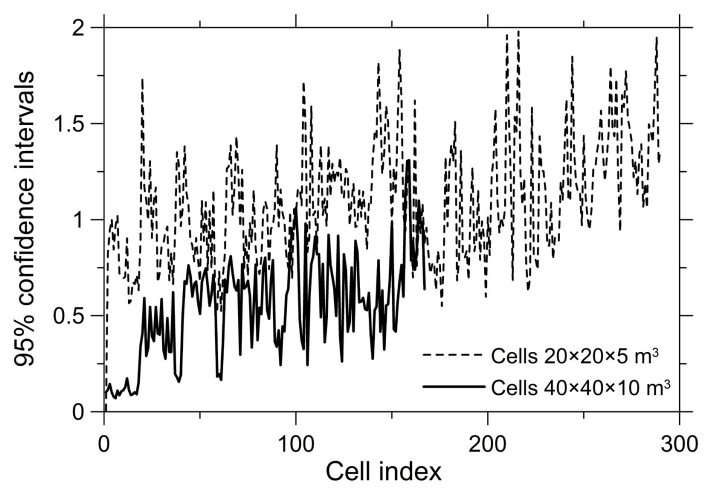

Fig. 4. The $95 \%$ confidence intervals computed considering the discretization of the matrix A: (a) cells of $40 \mathrm{~m} \times 40 \mathrm{~m} \times 10 \mathrm{~m}$; (b) cells of $20 \mathrm{~m} \times 20 \mathrm{~m} \times 5 \mathrm{~m}$.

show four $20 \mathrm{~m} \times 20 \mathrm{~m} \times 5 \mathrm{~m}$ cells. Figure $5 \mathrm{~b}$ shows a crosssection corresponding to profile A-B in Fig. 5a: depending on the location within the loop area, the same volume of water may generate four different amplitudes. This heterogeneous and asymmetric sensitivity of the SNMR loop is due to the inclination of the geomagnetic field and to the elliptical polarization of the loop's magnetic field (Weichmann et al., 2000; Girard et al., 2007; Hertrich, 2008). Thus, modeling results show that small targets cannot be resolved with 3-D-SNMR inversion and consequently small water volumes cannot be accurately measured with one SNMR loop. However, if we use a 3-D field setup consisting of several overlapping loops, then areas with a different sensitivity for different loops will overlap and the overall sensitivity within the 3-D setup will be much more homogeneous.

Water within a glacier occurs in caverns and fractures of different size and location. Each small reservoir has $100 \%$ of the water content, but as they are located in ice the water content averaged over the volume that can be resolved by 3 -D-SNMR inversion may be less than $100 \%$. For example, if an ice volume of $40 \mathrm{~m} \times 40 \mathrm{~m} \times 10 \mathrm{~m}$ contains a $20 \mathrm{~m} \times 20 \mathrm{~m} \times 5 \mathrm{~m}$ water-filled cavern, the water content es- a)

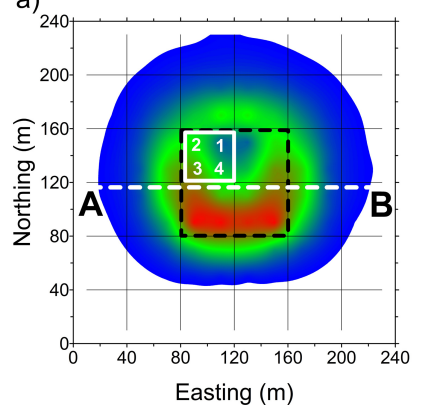

b)

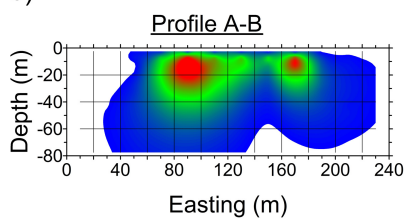

Max. amplitude (nV)

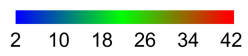

Fig. 5. 3-D sensibility of the SNMR loop computed for $20 \mathrm{~m} \times 20 \mathrm{~m} \times 10 \mathrm{~m}$ cells: (a) the amplitude of SNMR signal as a function of the cell location within the loop-affected area computed for the depth of $20 \mathrm{~m}$; (b) the amplitude of SNMR signal as a function of the cell location shown as a cross-section along profile A-B. The SNMR loop is shown with a dashed black line and cell size is shown with a white line. Four cells of $20 \mathrm{~m} \times 20 \mathrm{~m} \times 5 \mathrm{~m}$ are shown by numbers 1 to 4 within one $40 \mathrm{~m} \times 40 \mathrm{~m} \times 10 \mathrm{~m}$ cell.

timated with 3-D-SNMR in the ice volume will be $12.5 \%$ instead of $100 \%$ expected in the target volume and $0 \%$ in ice. If, additionally, the location of the target is not accurately known, then the SNMR estimate of the volume will be biased by the inhomogeneity of the sensitivity.

3-D-SNMR inversion uses regularization based on the smoothness constraint, which allows obtaining a stable solution, but may not be justified for the strongly heterogeneous water distribution in a glacier. Our numerical experiments consisted of the inversion of 3-D targets of different size and location; this provided the approximate location of the initial model, but in small targets the water volume may be overestimated up to twofold. We explain this by the regularization effect, as the inversion result is an image that results from a trade-off between the misfit and the smoothness constraint. Misfit is directly linked to water volume through the integral equation, but the smoothness constraint represents an assumption on the solution shape and physically is not linked to water volume. For example, if a cell produces a small signal, then the volume of water in this cell will have a small effect on the misfit. However, the smoothness constraint will attribute to this cell a water content equal to that in the neighboring cells, thus increasing the volume estimate, which is not justified by the data.

To cope with this heterogeneous SNMR sensitivity in the measuring setup and a limited resolution of the 3-D-SNMR inversion, we developed an interpretation approach based on a learning procedure. As a learning procedure, we simulated numerical models of different size and location using measuring conditions corresponding to a field survey. Interpretation of the synthetic and experimental data was carried out in two steps: a smooth inversion with the regularization followed by forward modeling. First, smooth 3-D inversion provided an approximate volume and location of water in the 


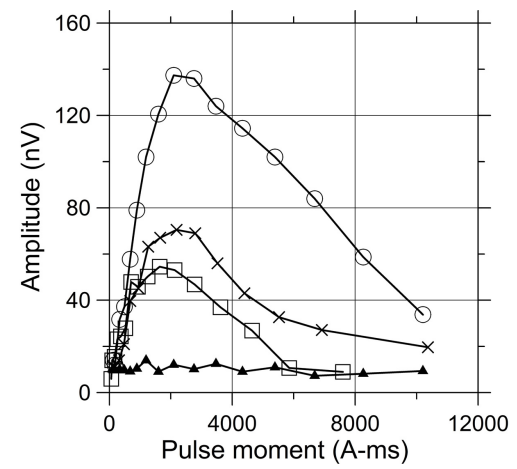

Fig. 6. Amplitude of the SNMR signal vs. pulse moment measured with loop no. 1. Circles show the amplitude measured in 2009 when the cavern was undisturbed by pumping $\left(V=53500 \mathrm{~m}^{3}\right)$, crosses correspond to 2011 data $\left(V=18500 \mathrm{~m}^{3}\right)$ and squares are 2012 measurements $\left(V=11200 \mathrm{~m}^{3}\right)$. Triangles show measurements of the ambient electromagnetic noise.

glacier without any prior knowledge of the solution. After that, the obtained image of the water distribution was approximated by a model consisting of several boxes. The number, location and water content in each box were selected so that the computed theoretical signal would fit the experimental data. For estimating the minimum and maximum possible amounts of water that can explain the measured signals, we used models with water located in areas with high and low sensitivities of the SNMR loops. Below, we discuss that this expert approach produced good results when applied to investigations of the Tête Rousse glacier.

\section{Experimental results}

Nine loops were used between 2009 and 2011 (Fig. 2; black squares) and three additional loops were added for surveys carried out in 2012 (red squares). We used NUMIS plus equipment manufactured by IRIS Instruments (France). Data processing and 3-D inversion were done with the SAMOVAR-11x4 software package developed at the Institut de Recherche pour le Développement (IRD, France).

\subsection{3-D-SNMR measurements}

Figure 2 shows the location of the central cavern as a horizontal slice at an elevation of $3124 \mathrm{~m}$, corresponding to a depth of $46 \mathrm{~m}$ below the glacier surface. Note that the average water content given by 3-D-SNMR inversion is $40 \%$ instead of the $100 \%$ expected for bulk water in the cavern. This discrepancy can be explained by the limited resolution of magnetic resonance imaging, which shows an area larger than the true cavern with a water content averaged over this larger area. The water reservoir may also have a complex geometry unresolved by the inversion.

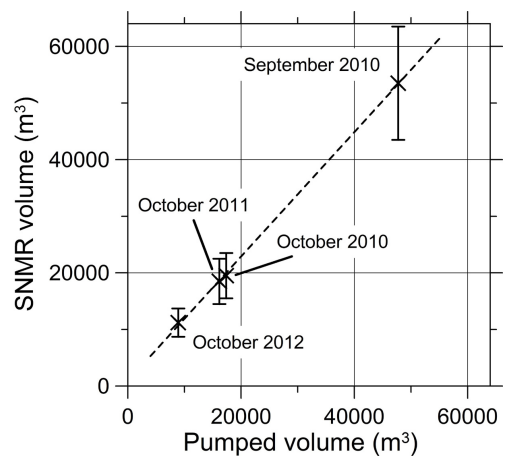

Fig. 7. 3-D-SNMR water volume estimated before each pumping against the water volume extracted by pumping.

Figure 6 shows the amplitude of the SNMR signal vs. pulse moment, measured with loop no. 1 located over the central cavern (see Fig. 2 for location). The measurements were carried out at different periods, when the cavern contained different volumes of accumulated water. In all three cases, the measured SNMR signal was significantly larger than the ambient electromagnetic noise. The smaller signal thus corresponds to smaller volumes of water, which demonstrates the sensitivity of the method to water-volume variations.

\subsection{Water volume estimate}

Between 2010 and 2012, the central cavern was drained three times, and once we conducted 3-D-SNMR measurements during such pumping. A 3-D-SNMR survey carried out in June 2010 did not detect any changes in the water distribution between September 2009 and June 2010, and we assume that the 3-D-SNMR results obtained in 2009 can be compared with the pumping results obtained in 2010. Thus, we have four points for comparing 3-D-SNMR estimates of the water volume and the volume extracted by pumping from this cavern. A summary of the measurements of the water volume accumulated in the central cavern using 3-D-SNMR and pumping is presented in Table 1. Figure 7 shows a good correlation (dashed line) between the water volume estimated by 3-D-SNMR and that extracted by pumping.

Further comparison with the pumping data shows that 3D-SNMR consistently overestimated the volume of water relative to that extracted by pumping. The average discrepancy between 3-D-SNMR and pumping was calculated as approximately $3100 \mathrm{~m}^{3}$. At least some part of this volume can be attributed to residual water remaining in the glacier after pumping, because technically it is impossible to extract all the water. Moreover, water in hydraulically disconnected caverns and channels contributes to the SNMR signal, but cannot be pumped out. It is also known that the water content in temperate ice usually varies between 0.7 and $2.5 \%$ (Lliboutry, 1976; Bradford et al., 2009) and may be as high 
Table 1. Summary of measurements of the water volume accumulated in the central cavern using 3-D-SNMR and pumping.

\begin{tabular}{|c|c|c|c|c|c|c|c|c|c|c|}
\hline \multirow[t]{2}{*}{ Action } & \multicolumn{10}{|c|}{ Schedule } \\
\hline & $\begin{array}{r}5- \\
16 / 09 / 2009\end{array}$ & $\begin{array}{r}26 / 08- \\
15 / 10 / 2010\end{array}$ & $\begin{array}{r}25- \\
28 / 09 / 2010\end{array}$ & $\begin{array}{r}28 / 09- \\
15 / 10 / 2010\end{array}$ & $\begin{array}{r}3- \\
9 / 06 / 2011\end{array}$ & $\begin{array}{r}22- \\
24 / 09 / 2011\end{array}$ & $\begin{array}{r}26 / 09- \\
9 / 10 / 2011\end{array}$ & $\begin{array}{r}22- \\
24 / 06 / 2012\end{array}$ & $\begin{array}{r}14- \\
22 / 08 / 2012\end{array}$ & $\begin{array}{r}24 / 09- \\
8 / 10 / 2012\end{array}$ \\
\hline $\begin{array}{l}\text { 3-D-SNMR } \\
\text { volume }\left(\mathrm{m}^{3}\right)\end{array}$ & 53500 & & 19500 & & 7000 & 18500 & & 8500 & 11200 & \\
\hline $\begin{array}{l}\text { Pumped } \\
\text { volume }\left(\mathrm{m}^{3}\right)\end{array}$ & & 47728 & & 17362 & & & 16162 & & & 8904 \\
\hline $\begin{array}{l}\text { Discrepancy } \\
\left(\mathrm{m}^{3}\right)\end{array}$ & & 5572 & & 2138 & & & 2338 & & & 2296 \\
\hline $\begin{array}{l}\text { Discrepancy } \\
(\%)\end{array}$ & & 10.8 & & 11 & & & 12.6 & & & 20.5 \\
\hline
\end{tabular}

as $9 \%$ (Pettersson et al., 2004). This water will increase the SNMR signal, but only part of it can be pumped out.

The location of the temperate ice in the Tête Rousse glacier was approximately known (Gilbert et al., 2012; Vincent et al., 2012b) and we estimated its potential water volume by performing SNMR measurements outside the cavern location. Our estimate showed not more than $2 \%$ of water in temperate ice. More accurate estimates were limited by the insufficient signal-to-noise ratio for small water contents. To this end, for areas occupied by temperate ice we added $2 \%$ water content to the model of the water-filled cavern in the glacier body. Modeling results showed that up to $2000 \mathrm{~m}^{3}$ of the water volume measured by 3-D-SNMR may represent the contribution of water in temperate ice. However, the pumping operations took 44 days in 2010, 13 days in 2011 and 17 days in 2012, during which the cavern was continuously recharged. The recharge rate was unknown, but as snow melt on the Tete Rousse glacier in September/October is minimal, the recharge can be assumed to be slightly higher than in winter (20 to $30 \mathrm{~m}^{3} \mathrm{~d}^{-1}$ ). Therefore, an additional water volume of 250 to $1200 \mathrm{~m}^{3}$ was expected in the cavern; this contributed to the pumping results, but could not be taken into account by the 3-D-SNMR estimate. All these processes are difficult to quantify, but they cause additional inaccuracy of the volume estimates made by both 3-D-SNMR and pumping.

\subsection{Monitoring}

Twice a year, we carried out magnetic resonance measurements that allowed imaging about $75 \%$ of the glacier body. Each 3-D-SNMR campaign provided a water distribution within the glacier and an estimate of the water volume. Measurements were made in early June, after winter recharge, and in September after the summer recharge.

The central cavern, discovered in 2009, was the starting point of our monitoring. The 3-D image of the cavern presented in Fig. 8 consists of horizontal slices of the water content at different altitudes, showing the cavern location within the glacier. The repeated 3-D-SNMR measurements provided time-lapse images of the cavern. For example, Fig. 8
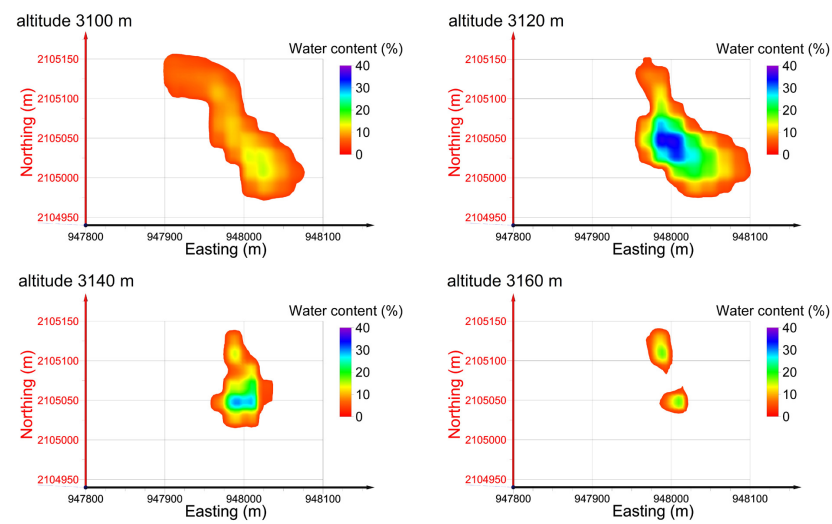

Fig. 8. 3-D-SNMR image of the water-filled cavern observed in September 2009 and shown as slices at different altitudes.

shows the undisturbed cavern observed in 2009 and Fig. 9 shows the same cavern imaged in 2011 after one drainingand-refilling cycle. Comparison of these images shows that the cavern remained in the same place, but that the draining caused changes in the cavern geometry and in the watercontent distribution. In 2011, the maximum water content was estimated at $15 \%$ instead of the $40 \%$ observed in 2009 , pointing to a smaller cavity and a smaller volume of water in the cavern in 2011.

To compare SNMR and pumping results, a 3-D-SNMR image can be transformed into a 1-D plot of the water volume per unit depth for different elevations. For this, we performed integration in the $x$ and $y$ directions of the 3-D water distribution $w(\boldsymbol{r})$ provided by inversion. The 3-D-SNMR and pumping results obtained between 2009 and 2012 are shown in Figs. 10 and 11. In Fig. 10, the volume of accumulated water derived from the 3-D-SNMR results is plotted vs. depth and is compared with the volume of water extracted by pumping. We observe a generally good correspondence between SNMR and pumping data for the depth interval corresponding to the main cavern volume. However, at the bottom of the cavern, the correlation is not as good as for the shallow part, because of a more complex geometry of the deeper 

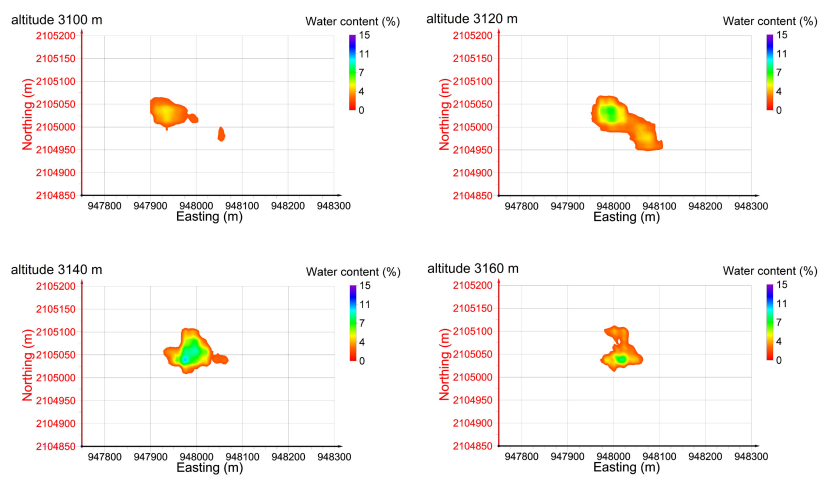

Fig. 9. 3-D-SNMR image of the water-filled cavern observed in September 2011 and shown as slices at different altitudes.

a)

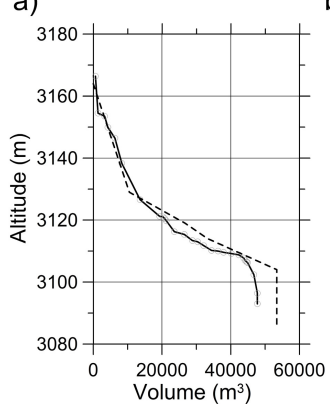

b)

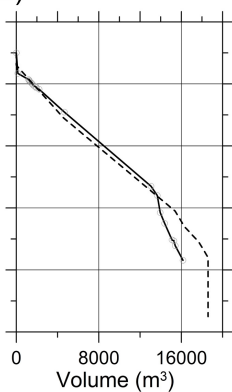

c)

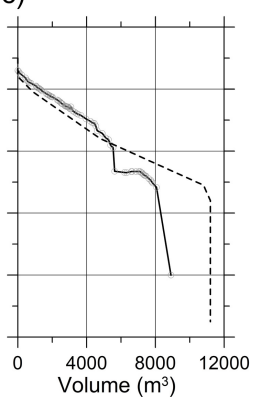

Fig. 10. Accumulated water volume vs. depth extracted by pumping (solid line) and water volume estimated with 3-D-SNMR (dashed line): (a) August-October 2010; (b) September-October 2011; (c) August 2012.

part of the cavern where 3-D-SNMR tends to overestimate the water volume due to processes discussed in Sect. 5.2. When the cavern was larger (2009 to 2011), the correlation was better than in 2012, probably because the cavern geometry became more complex after the first drainage. Figure 11 shows the water volume per unit depth vs. depth derived from 3-D-SNMR and pumping results, which are derivatives of the functions shown in Fig. 10. The correlation is generally good, but the rapid variations in extracted volume, observed by pumping, were not resolved by the 3-D-SNMR inversion. Figure 11 clearly shows that the main reservoir discovered in 2009 was located below $3125 \mathrm{~m}$ and that it became significantly smaller after the first draining-refilling cycle. In 2012, water was only observed above $3125 \mathrm{~m}$. A summary of the water-volume monitoring is shown in Table 2.

\subsection{Recharge of the central cavern}

During our monitoring, the cavern was continuously recharged. The results of water-volume measurements are shown in Fig. 12, indicating that the water volume in the fully recharged cavern was reduced after each draining-refilling cycle. In one year, the cavern lost about $65 \%$ of its vol-

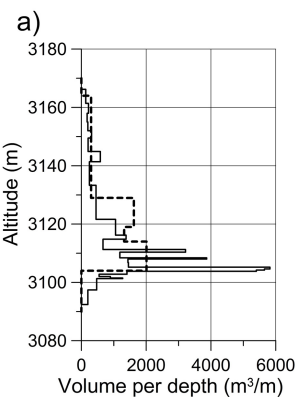

b)

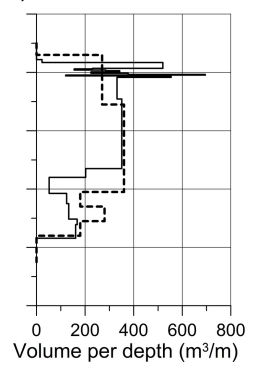

c)

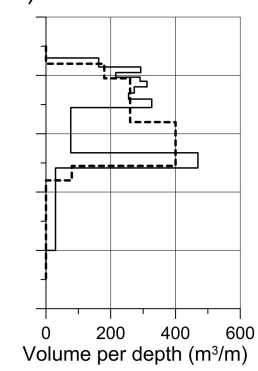

Fig. 11. Water volume per unit depth extracted from different depth intervals (solid line) and water volume per unit depth estimated with the 3-D-SNMR (dashed line): (a) August-October 2010; (b) September-October 2011; (c) August 2012.

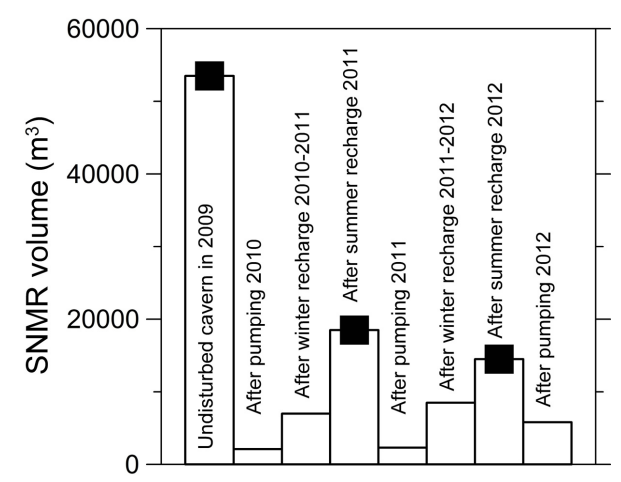

Fig. 12. Monitoring of the water volume accumulated in the central part of the Tête Rousse glacier between 2009 and 2012. Black squares show the volume after full recharge.

ume, and after two years it was reduced by about $73 \%$. Note that in Tables 1 and 2 the water volume observed in 2012 $\left(11200 \mathrm{~m}^{3}\right)$ corresponds only to water in the central cavern that was drained, thus allowing comparison between 3-DSNMR and pumping. In Fig. 12, however, we consider all water observed in the glacier $\left(14500 \mathrm{~m}^{3}\right)$, including $3300 \mathrm{~m}^{3}$ in a small cavern, which was imaged but not affected by pumping.

For estimating the recharge rate, we used the 3-D-SNMR estimates of water volume. Regular magnetic resonance measurements were made in early June for estimating the winter recharge rate, and in August or September for estimating the summer recharge rate. The average recharge rate was estimated as

$Q_{n}=\left(V_{n+1}-V_{n}\right) /\left(t_{n+1}-t_{n}\right)$,

where $V_{n}$ is the water volume in the cavern corresponding to the $n$th measurement, $t_{n}$ is time, and $n=0,1,2, . ., N$.

The average recharge rate observed between 2010 and 2012 is shown in Fig. 13. The summer recharge rate was estimated to be between 120 and $180 \mathrm{~m}^{3} \mathrm{~d}^{-1}$, and recharge continued throughout the winter at an average rate of 20 to 
Table 2. Summary of the 3-D-SNMR and pumping estimates of the changes in water volume in the central cavern caused by drainage. Evolution of the volume was estimated relative to the initial volume observed in 2010.

\begin{tabular}{lrrrrrr}
\hline Method & $\begin{array}{r}\text { Depth interval } \\
(\mathrm{m})\end{array}$ & $\begin{array}{r}2010 \\
\left(\mathrm{~m}^{3}\right)\end{array}$ & $\begin{array}{r}2011 \\
\left(\mathrm{~m}^{3}\right)\end{array}$ & $\begin{array}{r}2012 \\
\left(\mathrm{~m}^{3}\right)\end{array}$ & $\begin{array}{r}\text { Evolution } \\
2010-2011 \\
(\%)\end{array}$ & $\begin{array}{r}\text { Evolution } \\
2011-2012 \\
(\%)\end{array}$ \\
\hline Pumping & $3170-3125$ & 13617 & 13663 & 8464 & 0.3 & -38.2 \\
& $3125-3095$ & 34111 & 2499 & 440 & -92.7 & -6.0 \\
& $3170-3095$ & 47728 & 16162 & 8904 & -66.1 & -15.2 \\
\hline 3-D-SNMR & $3170-3125$ & 10600 & 11700 & 10800 & 10.4 & -8.5 \\
& $3125-3095$ & 42900 & 6800 & 400 & -84.1 & -14.9 \\
& $3170-3095$ & 53500 & 18500 & 11200 & -65.4 & -13.6 \\
\hline
\end{tabular}

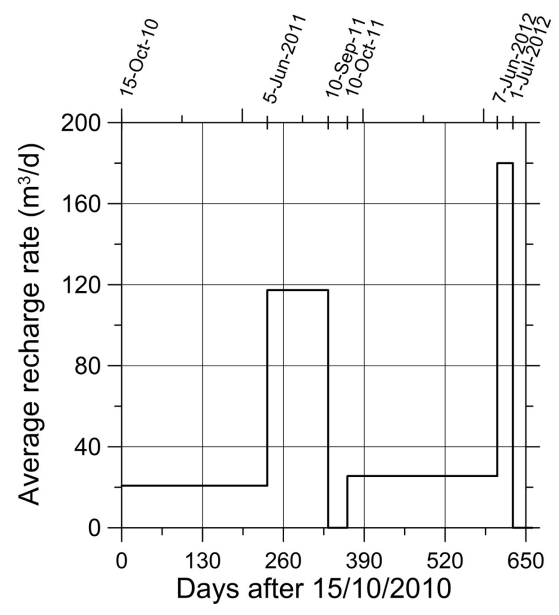

Fig. 13. Estimated average recharge rate of the cavern in the Tête Rousse glacier for the period between 15 October 2010 and $1 \mathrm{Au}-$ gust 2012.

$25 \mathrm{~m}^{3} \mathrm{~d}^{-1}$. We calculated the latter by considering the volume of residual water left in the cavern after pumping, which was estimated as the difference between the water volume given by 3-D-SNMR before pumping and the volume of water extracted by pumping (Table 1 ).

To explain such winter recharge, when no melting occurs at the glacier surface and only solid precipitation exists at this altitude, we looked for a water reservoir located at a higher elevation than the central cavern where water was not expected before. To that end, the measuring setup was extended towards the eastern part of the glacier (see Fig. 2 for location). The 3-D-SNMR image of the glacier obtained in 2012 using the additional loops (Fig. 14) in fact showed two distant reservoirs. Figure 14 shows water distribution starting from $3120 \mathrm{~m}$ because no water was observed below. The central reservoir is the cavern discovered in 2009; this became smaller and shallower in comparison with previous years, and its maximum water content was only $5 \%$ instead of the $15 \%$ observed in 2011 and the $40 \%$ in 2009 . The glacier surface was about $3173 \mathrm{~m}$ high at $948000^{\circ} \mathrm{E}$, thus showing that the central cavern was extended to the glacier surface (confirmed by boreholes). The second (upper) cavern is located at about $150-200 \mathrm{~m}$ east of the central cavern, at a higher elevation and in a dangerous area with difficult access. For this reason, accurate 3-D-SNMR imaging of this cavern was not possible in 2012. The 3-D-SNMR estimate of the water volume in the upper cavern suggests over $5000 \mathrm{~m}^{3}$, but this preliminary result requires further investigation. To verify the existence of a possible high-yield hydraulic link between the two caverns (tunnel or large channel), we took magnetic resonance measurements over the upper cavern before and immediately after draining of the central cavern, which showed that the 3-D-SNMR signal generated by water in the upper cavern did not change. This observation confirms that, if the pumping affected the upper cavern, this was below the detection threshold of the instrument.

\section{Discussion}

The annual drainage of a large cavern in the central part of the Tête Rousse glacier caused evolutionary rather than revolutionary changes in ice-cavern geometry, providing us with a rare opportunity of studying the glacier's transitional regime imposed by pumping. Tête Rousse thus is a real-scale physical model of a polythermal glacier, providing useful data that contribute to a better understanding of the different processes taking place in this type of glacier.

The use of 3-D-SNMR allowed quantifying the temporal and spatial changes in water distribution caused by the annual draining of a water-filled cavern. During our experiments, we confirmed that the 3-D-SNMR method is reliable and cost-effective compared to drilling and pumping for investigating water in a glacier. Unambiguous identification of liquid water in ice, localization of water-storage areas, and the possibility of estimating the water volume stored in a glacier are three advantages of 3-D-SNMR compared with traditional geophysical methods. In a highly heterogeneous environment, non-invasive imaging of a large area allows visualizing the entire glacier, which is a competitive advantage of 3-D-SNMR over drilling. Indeed, not all boreholes 


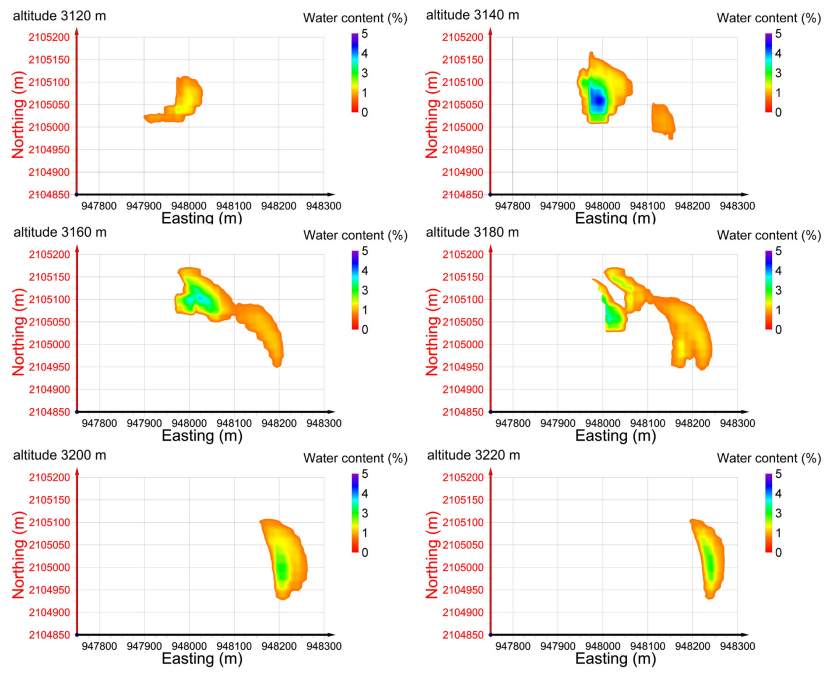

Fig. 14. 3-D-SNMR image of the water-filled cavern observed in October 2012 and shown as slices at different altitudes.

may be representative, and the need to drill many holes renders the fieldwork longer and more expensive (Gordon et al., 2001). Applied under glacier conditions, pumping may cause changes in the internal structure of the investigated glacier, but 3-D-SNMR is a non-destructive method. However, 3D-SNMR and pumping are complementary techniques that provide close, but different, visions of glacier hydrology. For example, 3-D-SNMR detects and visualizes water, regardless of whether or not a hydraulic link exists between different areas, but pumping may provide information on the hydraulic connection of different reservoirs.

Figure 14 shows that water in the Tête Rousse glacier accumulated in two separate reservoirs (central and upper caverns). The upper cavern would be preferentially recharged by melt water, but the central cavern may accumulate both surface and englacial water with corresponding refilling rates. Our results show that a large tunnel does not directly connect these two caverns, but that water may flow from the upper cavern through a subglacial drainage system and probably through subglacial sediment with a relatively low hydraulic conductivity. This slow drainage would explain the observed continuous recharge of the central cavern during the winter months. In summer, higher water fluxes may cause a higher hydraulic conductivity of the englacial channels (Raymond et al., 1995; Hubbard et al., 1995), as well as more water flow on the ice surface. Such increased water circulation may explain the higher summer-recharge rate observed during our monitoring. However, the subglacial drainage system in the Tête Rousse glacier is still not well known, and different drainage mechanisms typical for a polythermal glacier may coexist (Fountain and Walder, 1998).

The possibility of cavern-roof collapse during pumping was not excluded (Gagliardini et al., 2011). For security reasons, the glacier surface was under direct observation and small movements were continuously monitored with a differential GPS. In July 2012, a large crevasse appeared and ice deformation became visible on the surface over the cavern location, indicating that the latter caused this deformation. Monitoring of water accumulated in the glacier showed that, before 2012, each pumping event caused the volume of water in the central cavern to diminish. Both 3-D-SNMR and pumping results reveal that in one year (2010-2011) the cavern lost about $90 \%$ of the volume in its deeper part below $3125 \mathrm{~m}$ (Table 2). The relatively rapid rate of temperate ice deformation may explain these observations. For example, Reynaud (1987) observed a $60 \%$ reduction in inactive, englacial conduit at depths of about $100 \mathrm{~m}$ over a 20-day period. In addition, it cannot be excluded that part of the reduced volume of accumulated water may be attributed to air pockets in drained and refilled voids within the ice body.

Despite the new knowledge about the Tête Rousse glacier that has been acquired over the past three years, we still have an incomplete understanding of the glacial-hydrological processes and of glacier-ice dynamics. For example, while a cold-ice barrier may explain the formation of the central cavern, the existence of the upper cavern was not expected. We hope to continue our monitoring, leading to the precise location and size of the upper cavern that will complete our understanding of the glacier structure, and of the ice-deformation processes taking place in the glacier.

\section{Conclusions}

Imaging of the water distribution in the Tête Rousse glacier showed two main water-storage areas and allowed estimating the volume of accumulated water. Continuous cavern recharge occurs both in summer and during the winter months. The summer recharge rate was estimated to be six to eight times higher than the winter one. Our monitoring results revealed significant changes in the internal glacier structure, caused by the artificial drainage. In one year, the cavern lost about $65 \%\left(30000 \mathrm{~m}^{3}\right)$ of its initial volume, which was explained by creep deformation of the surrounding ice after draining and the probably formation of air pockets within the ice. These observations provide useful information to decision makers for developing protection measures minimizing the risk of a catastrophic flood from the glacier.

For this study, we used a newly developed 3-D-SNMR imaging method that allowed visualizing the englacial water and estimating the volume of water accumulated within the Tête Rousse glacier. The 3-D-SNMR results were found to be in a good agreement with pumping results and other observations, thus confirming the high reliability and efficiency of 3-D-SNMR imaging. As far as we know, this is the first report of applying large-scale magnetic resonance imaging to monitoring water accumulation in a glacier. 
Acknowledgements. The town of Saint-Gervais (France), Service de Restauration des Terrains en Montagne (RTM), and the Préfecture de la Haute Savoie (France) funded this study. We thank N. Karr, F. Charles and V. Tairraz for useful advice and for helping with the field measurements. We also thank all the people who assisted us during this work. We acknowledge reviewers A. D. Booth and J. West for their critical comments that contributed to improving the presentation of our results.

Edited by: J. O. Hagen

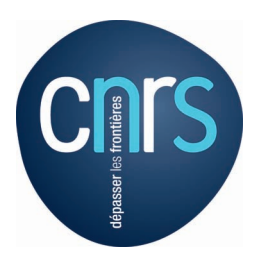

The publication of this article is financed by CNRS-INSU.

\section{References}

Aster, R. C., Borchers, B., and Thurber, C. H.: Parameter Estimation and Inverse Problems, Elsevier Academic Press, New York, 2005.

Bælum, K. and Benn, D. I.: Thermal structure and drainage system of a small valley glacier (Tellbreen, Svalbard), investigated by ground penetrating radar, The Cryosphere, 5, 139-149, doi:10.5194/tc-5-139-2011, 2011.

Benn, D., Gulley, J., Luckman, A., Adamek, A., and Glowacki, P. S.: Englacial drainage system formed by hydrologically driven crevasse propagation, J. Glaciol., 55, 513-523, doi:10.3189/002214309788816669, 2009.

Boucher, M., Girard, J. F., Legchenko, A., Baltassat, J. M., Dörfliger, N., and Chalikakis, K.: Using magnetic resonance soundings to locate a water-filled karst conduit, J. Hydrol., 330, 413421, doi:10.1016/j.jhydrol.2006.03.034, 2006.

Bradford, J. H., Nichols, J., Mikesell, T. D., and Harper, J. T.: Continuous profiles of electromagnetic wave velocity and water content in glaciers: an example from Bench Glacier, Alaska, USA, Ann. Glaciol., 50, 1-9, doi:10.3189/172756409789097540, 2009.

Callaghan, P. T., Dykstra, R., Eccles, C. D., Haskell, T. G., and Seymour, J. D.: A nuclear magnetic resonance study of Antarctic sea ice brine diffusivity, Cold Reg. Sci. Technol., 29, 153-171, doi:10.1016/S0165-232X(99)00024-5, 1999.

Endres, A. L., Murray, T., Booth, A. D., and West, L. J.: A new framework for estimating englacial water content and pore geometry using combined radar and seismic wave velocities, Geophys. Res. Lett., 36, L04501, doi:10.1029/2008GL036876, 2009.

Fischer, L., Kääb, A., Huggel, C. and Nötzli, J.: Geology, glacier changes, permafrost and related slope instabilities in a highmountain rock face: Monte Rosa east face, Italian Alps, Geophys. Res. Abstr., 7, 00518, doi:10.1029/2008GL036876, 2005.

Fountain, A. G. and Walder, J. S.: Water flow through temperate glaciers, Rev. Geophys., 36, 299-328, doi:10.1029/97RG03579, 1998.

Gagliardini, O., Gillet-Chaulet, F., Durand, G., Vincent, C., and Duval, P.: Estimating the risk of glacier cavity collapse during arti- ficial drainage: The case of Tête Rousse Glacier, Geophys. Res. Lett., 38, L10505, doi:10.1029/2011GL047536, 2011.

Gilbert, A., Vincent, C., Wagnon, P., Thibert, E., and Rabatel, A.: The influence of snow cover thickness on the thermal regime of Tête Rousse Glacier (Mont Blanc range, 3200 $\mathrm{m}$ a.s.1.): Consequences for outburst flood hazards and glacier response to climate change, J. Geophys. Res., 117, F04018, doi:10.1029/2011JF002258, 2012.

Girard, J. F., Boucher, M., Legchenko, A., and Baltassat, J. M.: 2-D magnetic resonance tomography applied to karstic conduit imaging, J. Appl. Geophys., 63, 103-116, doi:10.1016/j.jappgeo.2007.08.001, 2007.

Gordon, S., Sharp, M., Hubbard, B., Willis, I., Smart, C., Copland, L., Harbor, J., and Ketterling, B.: Borehole drainage and its implications for the investigation of glacier hydrology: experiences from Haut Glacier d'Arolla, Switzerland, Hydrol. Process., 15, 797-813, doi:10.1002/hyp.184, 2001.

Grasmueck, M., Weger, R., and Horstmeyer, H.: Three-dimensional ground-penetrating radar imaging of sedimentary structures, fractures, and archaeological features at submeter resolution, Geology, 32, 933-936, doi:10.1130/G20776.1, 2004.

Gross, R., Green, A. G., Horstmeyer, H., and Begg, J. H.: Location and geometry of the Wellington Fault (New Zealand) defined by detailed three-dimensional georadar data, Geophys. Res. Lett., 109, B05401, doi:10.1029/2003JB002615, 2004.

Hamran, S. E., Aarholt, E., Hagen., J. O., and Mo, P.: Estimation of relative water content in a sub-polar glacier using surfacepenetration radar, J. Glaciol., 42, 533-537, 1996.

Haeberli, W.: Frequency and characteristics of glacier floods in the Swiss Alps, Ann. Glaciol., 4, 85-90, 1983.

Haeberli, W., Alean, J. C., Müller, P., and Funk, M.: Assessing risks from glacier hazards in high mountain regions: some experiences in the Swiss Alps, Ann. Glaciol., 13, 96-102, 1989.

Hauck, C. and Vonder Mühll, D.: Using DC resistivity tomography to detect and characterise mountain permafrost, Geophys. Prospect., 51, 273-284, doi:10.1046/j.1365-2478.2003.00375.x, 2003.

Hauck, C., Guglielmin, M., Isaksen, K., and Vonder Mühll, D.: Applicability of frequency domain and time-domain electromagnetic methods, Permafrost Periglac., 12, 39-52, doi:10.1002/ppp.383, 2001.

Hertrich, M.: Imaging of groundwater with nuclear magnetic resonance, Prog. Nucl. Mag. Res. Sp., 53, 227-248, doi:10.1016/j.pnmrs.2008.01.002, 2008.

Hertrich, M., Green, A. G., Braun, M., and Yaramanci, U.: High-resolution surface NMR tomography of shallow aquifers based on multioffset measurements, Geophysics, 74, G47-G59, doi:10.1190/1.3258342, 2009.

Hoekstra, P.: Electromagnetic methods for mapping shallow permafrost, Geophysics, 43, 782-787, doi:10.1190/1.1440853, 1978.

Hubbard, B. P., Sharp, M. J., Willis, I. C., Nielsen, M. K., and Smart, C. C.: Borehole water-level variations and the structure of the subglacial hydrological system of Haut Glacier d'Arolla, Valais, Switzerland, J. Glaciol., 41, 572-583, 1995.

Irvine-Fynn, T. D. L., Moorman, B. J., Williams, J. L. M., and Walter, F. S. A.: Seasonal changes in groundpenetrating radar signature observed at a polythermal glacier, Bylot Island, Canada, 
Earth Surf. Proc. Land., 31, 892-909, doi:10.1002/esp.1299, 2006.

Irvine-Fynn, T. D. L., Hodson, A. J., Moorman, B. J., Vatne, G., and Hubbard, A. L.: Polythermal Glacier Hydrology: A review, Rev. Geophys., 49, RG4002, doi:10.1029/2010RG000350, 2011.

Jansson, P., Hock, R., and Schneider, T.: The concept of glacier storage: A review, J. Hydrol., 282, 116-129, doi:10.1016/S00221694(03)00258-0, 2003.

Kim, K. Y., Lee, J., Hong, M. H., Hong, J. K., Jin, Y. K., and Shon, H.: Seismic and radar investigations of Fourcade Glacier on King George Island, Antarctica, Polar Res., 29, 298-310, doi:10.1111/j.1751-8369.2010.00174.x, 2010.

Kneisel, C.: New insights into mountain permafrost occurrence and characteristics in glacier forefields at high altitude through the application of 2-D resistivity imaging, Permafrost Periglac., 15, 221-227, doi:10.1002/ppp.495, 2004.

Knight, R., Grunewald, E., Irons, T., Dlubac, K., Song, Y., Bachman, H. N., Grau, B., Walsh, D., Abraham, J. D., and Cannia, J.: Field experiment provides ground truth for surface nuclear magnetic resonance measurement, Geophys. Res. Lett., 39, L03304, doi:10.1029/2011GL050167, 2012.

Lanz, E., Maurer, H. R., Green, A. G., and Ansorge, J.: Refraction tomography over a buried waste disposal site, Geophysics, 63, 1414-1433, doi:10.1190/1.1444443, 1998.

Legchenko, A. V. and Shushakov, O. A.: Inversion of surface NMR data, Geophysics, 63, 75-84, doi:10.1190/1.1444329, 1998.

Legchenko, A. and Valla, P.: A review of the basic principles for proton magnetic resonance sounding measurements, J. Appl. Geophys., 50, 3-19, doi:10.1016/S0926-9851(02)00127$1,2002$.

Legchenko, A., Ezersky, M., Camerlink, C., Al-Zoubi, A., Chalikakis, K., and Girard, J. F.: Locating water-filled karst caverns and estimating their volume using magnetic resonance soundings, Geophysics, 73, 51-61, doi:10.1190/1.2958007, 2008.

Legchenko, A., Descloitres, M., Vincent, C., Guyard, H., Garambois, S., Chalikakis, K., and Ezerski, M.: Three-dimensional magnetic resonance imaging for groundwater, New J. Phys., 13, 025022, doi:10.1088/1367-2630/13/2/025022, 2011.

Lehmann-Horn, A., Walbrecker, J. O., Hertrich, M., Langston, G., McClymont, A. F., and Green, A. G.: Imaging groundwater beneath a rugged proglacial moraine, Geophysics, 76, B165-B172, doi:10.1190/geo2011-0095.1, 2011.

Lliboutry, L.: Physical processes in temperate glaciers, J. Glaciol., 16, 151-158, 1976.

Macheret, Y. and Glazovsky, A. F.: Estimation of absolute water content in Spitsbergen glaciers from radar sounding data, Polar Res., 19, 205-216, 2000.

Marescot, L., Loke, M. H., Chapellier, D., Delaloye, R., Lambiel, C., and Reynard, E.: Assessing reliability of 2D resistivity imaging in permafrost and rock glaciers using the depth of investigation index method, Near Surf. Geophys., 1, 57-67, doi:10.3997/1873-0604.2002007, 2003.

Maurer, H. and Hauck, C.: Instruments and Methods Geophysical imaging of alpine rock glaciers, J. Glaciol., 53, 110-120, doi:10.3189/172756507781833893, 2007.

Merz, K. J., Maurer, H. R., Rabenstein, L., Buchli, T., and Springman, S. M.: Geophysical characterization of unstable permafrost in the Turtmann Valley, Switzerland, Geophys. Res. Abstr., 14, EGU2012-2107, 2012.
Mougin, P. and Bernard, C.: Études exécutées au glacier de Tête Rousse, in: Annales de l'Observatoire météorologique, physique et glaciaire du Mont Blanc (altitude 4,358 métres), edited by: Vallot, J., Tome VI, Paris, 1905.

Murray, T., Stuart, G. W., Fry, M., Gamble, N. H., and Crabtree, D. M.: Englacial water distribution in a temperate glacier from surface and borehole radar velocity analysis, J. Glaciol., 46, 389398, doi:10.3189/172756500781833188, 2000.

Musil, M., Maurer, H., Green, A. G., Horstmeyer, H., Nitsche, F. O., Vonder Mühll, D., and Springman, S.: Shallow seismic surveying of an Alpine rock glacier, Geophysics, 67, 1701-1710, doi:10.1190/1.1527071, 2002.

Pettersson, R., Jansson, P., and Blatter, H.: Spatial variability in water content at the cold-temperate transition surface of the polythermal Storglaciären, Sweden, J. Geophys. Res., 109, F02009, doi:10.1029/2003JF000110, 2004.

Raymond, C. F., Benedict, R., Harrison, W., Echelmeyer, K., and Sturm, M.: Hydrological discharges and motion of Fels and Black Rapids Glaciers, Alaska, USA: Implications for the structure of their drainage systems, J. Glaciol., 41, 290-304, 1995.

Reynaud, L.: The November 1986 survey of the Grand Moulin on the Mer de Glace, Mont Blanc Massif, France, J. Glaciol., 33, 130-131, 1987.

Stoer, J. and Bulirsch, R.: Introduction to numerical analysis, Springer-Verlag Berlin, 1980.

Tarantola, A.: Inverse problem theory. Methods for data fitting and model parameter estimation, Elsevier Science Publ.Co., Inc., 1987.

Tikhonov, A. and Arsenin, V.: Solution of ill-posed problems: John Wiley \& Sons, Inc., 1977.

Valla, P. and Legchenko, A.: One-dimensional modelling for proton magnetic resonance sounding measurements over an electrically conductive medium, J. Appl. Geophys., 50, 217-229, doi:10.1016/S0926-9851(02)00141-6, 2002.

Vallot, J. and Delebecque, A.: Sur les causes de la catastrophe survenue à Saint-Gervais (Haute Savoie), C. R. Acad. Sci., 115, 264 266, 1892.

Vincent, C., Garambois, S., Thibert, E., Lefèbvre, E., Le Meur, E., and Six, D.: Origin of the outburst flood from Tête Rousse glacier in 1892 (Mont-Blanc area, France), J. Glaciol., 56, 688698, doi:10.3189/002214310793146188, 2010.

Vincent, C., Descloitres, M., Garambois, S., Legchenko, A., Guyard, H., Lefebvre, E., and Gilbert, A.: Detection of a subglacial lake in Glacier de Tete Rousse (Mont Blanc area, France), J. Glaciol., 58, 866-878, doi:10.3189/2012JoG11J179, 2012a.

Vincent, C., Descloitres, M., Garambois, S., Legchenko, A., Guyard, H., Thibert, E., Gilbert, A., Karr, N., and Tairraz, V.: Détection d'une poche d'eau au glacier de Tête Rousse en 2010 et mesures préventives pour éviter une catastrophe, La Houille Blanche, 2, 34-41, doi:10.1051/lhb/2012013, 2012b.

Vouillamoz, J. M., Legchenko, A., Albouy, Y., Bakalowicz, M., Baltassat, J. M., and Al-Fares, W.: Localization of saturated karst aquifer with magnetic resonance sounding and resistivity imagery, Ground Water, 41, 578-587, doi:10.1111/j.17456584.2003.tb02396.x, 2003.

Weichmann, P. B., Lavely, E. M., and Ritzwoller, M.: Theory of surface nuclear magnetic resonancewith applications to geophysical imaging problems, Phys. Rev. E, 62, 1290-1312, doi:10.1103/PhysRevE.62.1290, 2000. 